\title{
EVALUATION ACTIVITIES PERFORMANCE OF THE SPECIFIC INSTRUMENTAL TRANSVERSAL COMPETENCE IN SUBJECTS OF THE MECHANICAL ENGINEERING AREA
}

\author{
A.M. Pedrosa, E. Lozano-Mínguez, A. Besa, M.P. Vila, S. Martínez-Sanchís, \\ E.M. Sánchez-Orgaz
}

Universitat Politècnica de València (SPAIN)

\begin{abstract}
Nowadays, the European higher education area is concerned, not only about the transmission of theoretical knowledge, but also about the acquisition of soft-skills, which are increasingly demanded in the professional profiles of graduates. Therefore, the Universitat Politècnica de València (UPV) has elaborated its own program aiming to develop these generic capabilities, which are embedded in 13 Transversal Competences (CT in Spanish). All of them are worked on and evaluated in all UPV degrees, whether undergraduate or graduate. Specifically, the "Specific Instrumental" transversal competence has been working for two years by a team of lecturers from the Department of Mechanical and Materials Engineering (DIMM in Spanish). Their objective is to develop an effective methodology to work on the acquisition and evaluation of this competence. The tool chosen to work with is ANSYS $®$, which is widely used in the field of mechanical engineering. This commercial software provides numerical solutions to complex problems using the Finite Element Method (FEM).

The proposed methodology has been implemented during this year in three different subjects with a total of 335 students and is based on previous experience carried out in small groups last year. The objective is also to consolidate a procedure suitable for large groups without increasing lecturer's dedication time. After analysing the characteristics that were not entirely satisfactory, the new proposal seeks to improve them while maintaining the correct actions of the previous experience. Thus, laboratory training sessions and a different timed exercise for each student are kept. The most important changes affect the distribution of the worktime of the student and the assessable exercises. The number of evaluable exercises has been reduced to one, as well as the content and the test score. The proposed exercise consists of modelling a mechanical component and carrying out several tasks related to the mechanical study of a component. The correct completion of the different sections allows a numerical evaluation of the laboratory sessions and the suitability of the methodology. At the same time, the justification of the steps followed, and the adequacy of the strategies followed give the level reached in the "Specific Instrumental" transversal competence.

The results reveal that students have achieved a greater degree of autonomy in managing the software. Furthermore, the new evaluation system discriminates the mastery with greater rigor, in the past there were no intermediate marks, the capability was achieved or not. Additionally, all the practical sessions have been adapted to the sanitary situation following an online format. This adaptation to the COVID scenario has provided the opportunity to introduce changes in the lecturing material that will be maintained in the next courses.
\end{abstract}

Keywords: competence, methodology, evaluation, specific instrumental, learning, finite element software, COVID-19.

\section{INTRODUCTION}

The European Higher Education Area (EHEA) created the Tuning project [1], [2] with the aim of offering an approach to the Bologna process in the study area corresponding to higher education levels. It is a worldwide methodology that consists of designing, developing, applying, and evaluating the studies involved in the Bologna approach. Along the same lines, the Universitat Politècnica de València (UPV) has been working for years on its own Transversal Competences (which is abbreviated as CT in Spanish) project [3]. The main idea of these CTs is to evaluate students according to their level in 13 specific competences, which were proposed aiming to improve job placement after their studies. These thirteen competencies are: understanding and integration; application and practical thinking; analysis and problem solving; innovation, creativity and entrepreneurship; design and project; teamwork and leadership; ethical, environmental and 
professional responsibility; effective communication; critical thinking; knowledge of contemporary problems; lifelong learning; planning and time management; and specific instrumental (i.e. use of tools and technologies).

Based on the proposal of this methodology, the Institute of Education Sciences of the UPV carries out an annual call for Lecturing innovation, and Learning + Teaching, promoted by the Vice-Rector for Studies, Quality and Accreditation together with the Vice-Rector for Digital Resources and Documentation. Within this call is the Call for Educational Innovation and Improvement Projects (which is abbreviated as PIME in Spanish) [4].

Part of the Mechanical Engineering Department lecturers are currently participating in this PIME call. Their work is focused on the latest CT, i.e. the Specific Instrumental CT13. This competence aims to improve the student's skills in the identification and use of the most appropriate computer technologies and tools for the professional practice associated with each degree. Students must be able to utilise, integrate and combine them in order to solve a problem, carry out a project or an experiment. For this, certain subjects that work on CT13 have been selected, and the ability of students to acquire said competence has been evaluated after carrying out certain practical sessions. These are based on the management of a specific Mechanical Engineering software called ANSYS, that is based on the use of the Finite Element Method. The main idea is that the student is able to solve any mechanical problem raised using this software, together with their theoretical knowledge on the subject. The objective of this work is to propose an evaluation method capable of assessing the ability of students to solve these types of problems, in such a way that it clarifies whether the student has achieved the acquisition of the CT13.

\section{OBJECTIVES}

The main goal of the current work is to guide students to achieve the capability of identifying the most suitable tools, the knowledge of their utilities and how to combine them to solve problems, carry out projects or experiments.

In addition, this work tries to consolidate a common methodology to work on and to evaluate the specific instrumental transversal competence (CT-13 according to the UPV standards [3]) in a similar way in the practical sessions of different subjects with groups of students of any size.

Moreover, the proposed methodology aims to be valid in both face-to-face and online teaching scenarios, considering that the trend opened after the global pandemic situation places flexibility as a necessary characteristic on education in the close future.

\section{METHODOLOGY}

The specific instrument selected is the commercial software ANSYS $₫$ [5]. This simulation software allows to model and solve any problem in physics that can be model with partial derivative equations. For this reason, ANSYS ${ }^{8}$ is a powerful tool commonly used in the professional tasks of a mechanical engineer by predicting the behave of a mechanical system, among others. As it is an applied modelling and calculation tool, the proposed methodology exclusively affects the practical sessions of the subjects.

\subsection{Previous experience}

During the first year (Course 19-20), the experience was carried out in three subjects with less than 20 students each of them [6]. In the practical sessions, students followed a very detailed guide where all the steps were deeply explained. They also could check their work by comparing part of their partial results with those in the booklet. Students did not model exactly the same system, some differences appear between the exercises, such as the geometry (Figure 1a)), the value of the applied pressure (Figure 1b)) or a parameter that students had to select freely as the size of the elements. 


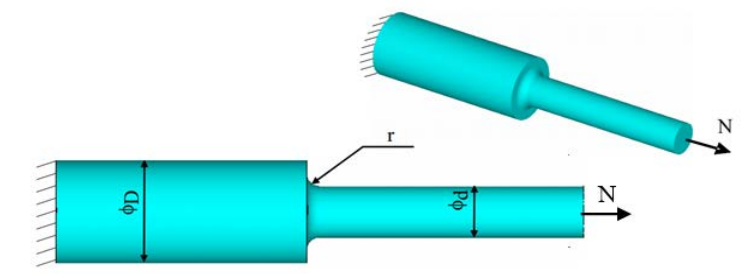

\begin{tabular}{|c|c|c|c|c|c|c|}
\cline { 2 - 7 } \multicolumn{1}{c|}{} & A1 & A2 & A3 & A4 & A5 & A6 \\
\hline d (m) & 0.05 & 0.1 & 0.15 & 0.2 & 0.25 & 0.3 \\
\hline
\end{tabular}

\begin{tabular}{|l|c|c|c|c|}
\cline { 2 - 5 } \multicolumn{1}{c|}{} & B1 & B2 & B3 & B4 \\
\hline D/d & 1.5 & 1.75 & 2.0 & 2.25 \\
\hline
\end{tabular}

\begin{tabular}{|c|c|c|c|c|c|}
\cline { 2 - 6 } \multicolumn{1}{c|}{} & C1 & C2 & C3 & C4 & C5 \\
\hline r/d & 0.10 & 0.125 & 0.15 & 0.175 & 0.20 \\
\hline
\end{tabular}

a)

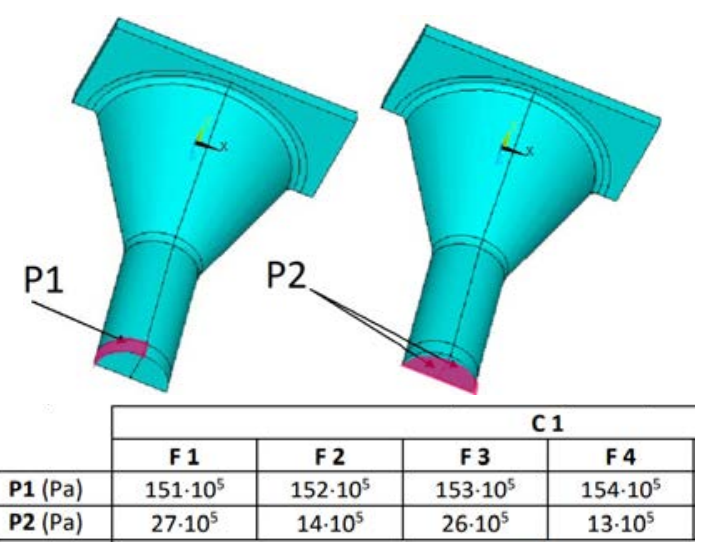

b)

Figure 1. Differences between models: a) In geometry; b) In boundary conditions

In the guided sessions, students uploaded several files according to the steps required to model the exercise (geometry, FE mesh, boundary conditions, solution of the calculation, etc.), and answered some questions related to the theory of the subject (value of the stress-concentration factor, proper theory to predict the failure depending on the material behaviour, etc.).

At the end of every practical session, students had to model and solve a similar problem (see Figure 2 ) without any instructions and to justify the selection of the parameters employed in the model. With this activity, students maintained an active attitude during the guided exercise to learn enough to solve the individual problem autonomously. Their explanations related to the followed steps could show their level of domain of the CT-13 competence.

That proposal was partially success. Regarding the students' attitude, in all the subjects they seemed to be more interested in learning during the practical lessons, comparing with the previous years without the unguided activity. Their attention was focused not only in reproducing each of the steps of the procedure but also in understanding the effect of each design parameter (symmetries, size of the elements, etc.) in the final solution. However, most of them could not finished the individual exercise during the practical session. The deadline for the task was extended, by cons, the authorship of the work could not be guaranteed. Over the last year, an evolution in the student's learning was observed, in the last sessions the deliveries on time increased and the delay time was reduced.

Regarding the required justification of the steps followed in the model, students did not seem to understand how to specify them, since most of them did not answered or gave vague answers.

In conclusion, the individual exercise made them to be aware during the practical sessions, so it had to be maintained, but some aspects had to be revised.

\subsection{New proposal}

After the analysis of the previous experience the methodology has been redesigned in order to maintain the successful actions and try to improve those aspects less satisfactory.

\subsubsection{Guided sessions}

The guided sessions follow a similar structure of the previous years but due to the pandemic, they have been adapted to online sessions. During the first fifteen minutes, the lecturer gives the general guidelines for modelling the piece on ANSYS ${ }^{\circ}$, then explains how to deliver the exercises and finally distributes the data to each student. After the general introduction, students can contact the lecturer to ask questions. To help the students' autonomy, the booklet has been reviewed. Paragraphs that students used to find more difficult to understand have been rewritten and added additional figures or links to videos. The deliver consists of uploading figures and files with the evidence of the steps followed and fulfilling a form with the theoretical questions. 


\subsubsection{Unguided final session}

Regarding the number of individual exercises, the new proposal maintains only one exercise which is made in a final session at the end of the year. The final exercise is different for each student, and it consists of modelling a similar geometry of one of the exercises made during the guided practical sessions, i.e. one of those that students solved in every session in the previous year.

The Figure 2 shows two examples: a) corresponds to the geometries modelled during the lab sessions, and b) are the corresponding similar geometry of the final unguided exercise.
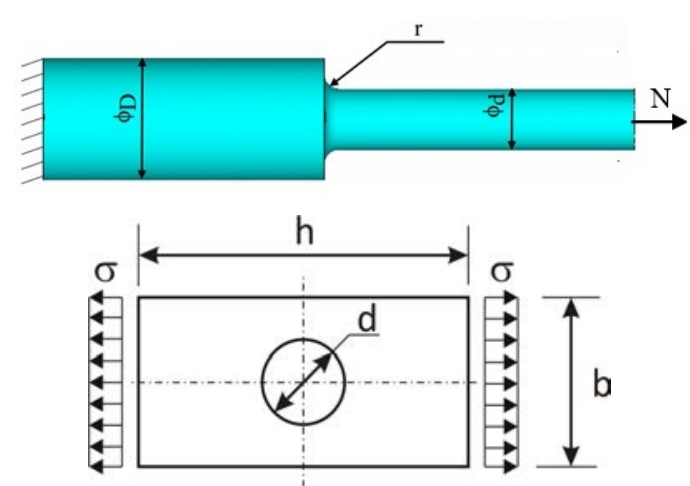

a)
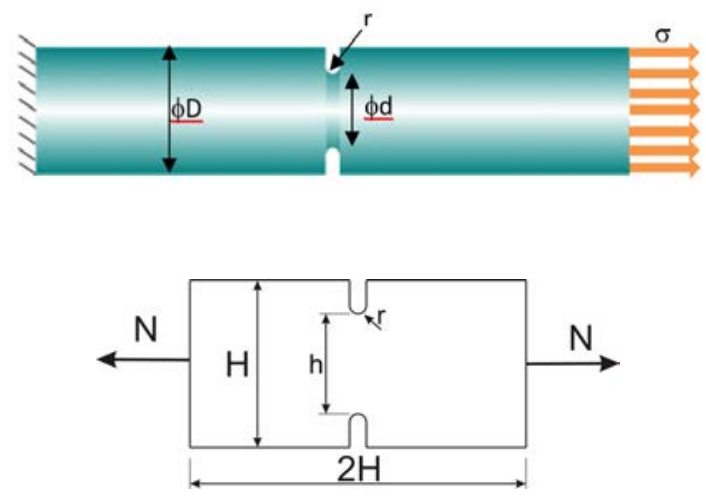

b)

Figure 2. a) Guided exercise; b) Final unguided exercise

Unlike in the guided sessions, students only have a statement with the geometry, the characteristics of the material, and the value of the applied pressure.

To complete the final exercise, students may follow the corresponding steps, which are: to configure the menus of the software, apply simplifications in the geometry derived from symmetry, choose the type and the size of the elements of the discretization, define the characteristics of the materials, apply boundary conditions, do the calculations, and to provide the required solution. With a view to measuring the degree of mastery of the competences, students must justify the selection of the model parameters. In the new proposal the required justifications have been better detailed. The Figure 3 shows the evolution.

\section{a) Year 2019-20}

Justify how was made the model, both the geometric definition and the chosen boundary conditions, as well as the generation of the mesh.

b) Year $2020-21$

2 DEFINITION OF THE GEOMETRY:

Describe and justify how was made the model in ANSYS

\begin{tabular}{|l|l|}
\hline $\begin{array}{l}\text { Simplifications } \\
\text { in geometry }\end{array}$ & \\
\hline $\begin{array}{l}\text { Boundary } \\
\text { conditions }\end{array}$ & \\
\hline
\end{tabular}

3 MESH

Justify here the criteria to select the element size

4 RESULTS
Compare the stress concentration factor $(\mathrm{Kt})$ obtained with ANSYS and that of the graph. Justify the differences

Figure 3. Evolution of the required justification (translated) 
Finally, to validate the numerical results obtained with ANSYS $®$, the theoretical results are provided together with the statement. The Figure 4 shows the graphs where students can compare the value of the stress-concentration factor obtained with their model, as well as correct their model if it is necessary.
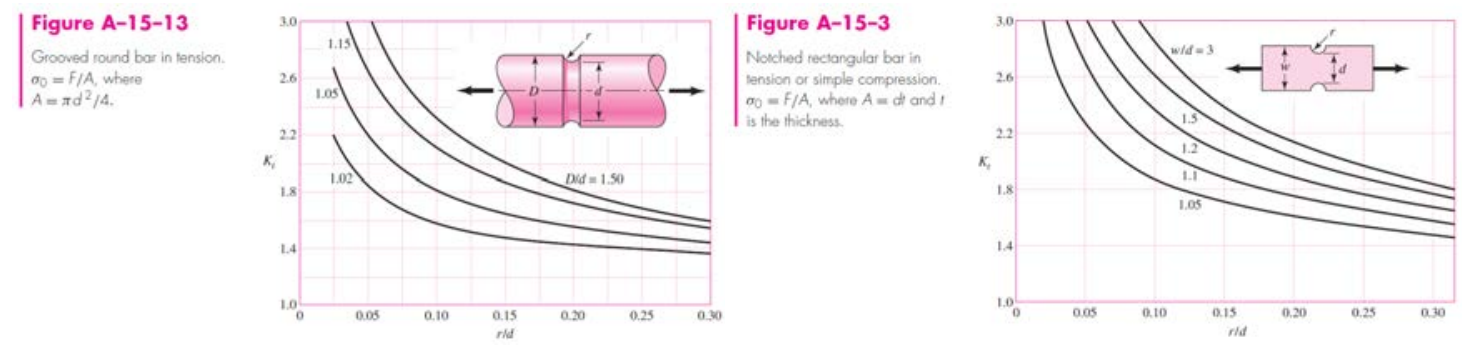

Figure 4. Graphs of the stress-concentration factor [7].

\subsubsection{Evaluation}

Regarding the evaluation, two different aspects have been considered: the number of correct results achieved and the mastery of the software. The former is evaluated with a traditional method while, for the latter, a rubric has been elaborated to better discriminate the level reached. Figure 5 shows an example of a rubric employed.

2 DEFINITION OF GEOMETRY

\begin{tabular}{|l|l|l|l|l|l|}
\hline CRITERIA & 0- Not done & 1- Poor & 2- Fair & 3- Good \\
\hline $\begin{array}{l}\text { Apply symmetry to } \\
\text { the geometric } \\
\text { model }\end{array}$ & $\begin{array}{l}\text { Make mistakes in } \\
\text { geometry or does not } \\
\text { apply symmetries }\end{array}$ & $\begin{array}{l}\text { Make mistakes in } \\
\text { geometry and apply some } \\
\text { of the symmetries }\end{array}$ & $\begin{array}{l}\text { Model the part correctly } \\
\text { but does not apply any } \\
\text { symmetry }\end{array}$ & $\begin{array}{l}\text { Model the part correctly. } \\
\text { Follows the example and } \\
\text { applies half symmetry }\end{array}$ & $\begin{array}{l}\text { Model the part correctly. } \\
\text { Go further and apply more } \\
\text { advantageous symmetry } \\
\text { conditions than those } \\
\text { explained in class (a } \\
\text { quarter or an eighth) }\end{array}$ \\
\hline $\begin{array}{l}\text { Boundary } \\
\text { conditions }\end{array}$ & $\begin{array}{l}\text { Does not apply boundary } \\
\text { conditions }\end{array}$ & $\begin{array}{l}\text { Does not apply stress. } \\
\text { Some boundary condition } \\
\text { is missing }\end{array}$ & $\begin{array}{l}\text { Does not fix a point (rigid } \\
\text { body movement) } \\
\text { Pressure with wrong sign }\end{array}$ & $\begin{array}{l}\text { Correct symmetry } \\
\text { conditions with half } \\
\text { symmetry. } \\
\text { Correct pressure }\end{array}$ & $\begin{array}{l}\text { Correct symmetry } \\
\text { conditions with a quarter } \\
\text { or an eighth symmetry. } \\
\text { Correct pressure }\end{array}$ \\
\hline
\end{tabular}

3 MESHING

\begin{tabular}{|c|c|c|c|c|c|}
\hline CRITERIA & 0 - Not done & 1- Poor & 2-Fair & 3-Good & 4- Excellent \\
\hline $\begin{array}{l}\text { Correct meshing } \\
\text { with refinement } \\
\text { Correct meshing } \\
\text { with refinement }\end{array}$ & No mesh done & $\begin{array}{l}\text { Mesh with an element not } \\
\text { proposed. } \\
\text { Mesh with the proposed } \\
\text { element, but does not } \\
\text { apply refinement level } 1 \text { or } \\
\text { refine in the stress } \\
\text { concentrator }\end{array}$ & $\begin{array}{l}\text { Mesh with the proposed } \\
\text { element but does not } \\
\text { apply refinement level } 1 \text { or } \\
\text { does not refine in the } \\
\text { stress concentrator (only } \\
\text { applies one of the two } \\
\text { refinements) }\end{array}$ & $\begin{array}{l}\text { Mesh with the proposed } \\
\text { element. } \\
\text { Apply refinement level } 1 \\
\text { and refine in the stress } \\
\text { concentrator following the } \\
\text { correct procedure }\end{array}$ & $\begin{array}{l}\text { Mesh with the proposed } \\
\text { element. } \\
\text { Applies refinement level } 1 \\
\text { and refines in the stress } \\
\text { concentrator improving } \\
\text { the proposal of the } \\
\text { statement }\end{array}$ \\
\hline
\end{tabular}

4 RESULTS

\begin{tabular}{|c|c|c|c|c|c|}
\hline CRITERIA & 0- Not done & 1- Poor & 2-Fair & 3-Good & 4- Excellent \\
\hline Solución nodal & Does not present results & $\begin{array}{l}\text { Does not show nodal } \\
\text { solution. Presents a } \\
\text { different solution } \\
\text { (element instead of nodal) } \\
\text { or the selected quantity } \\
\text { does not represent the } \\
\text { required solution (for } \\
\text { example, displacement) }\end{array}$ & $\begin{array}{l}\text { The nodal solution } \\
\text { provided in the table does } \\
\text { not match with the image. } \\
\text { Errors in units }\end{array}$ & Choose a correct stress & $\begin{array}{l}\text { Choose a correct stress } \\
\text { and justify that is the one } \\
\text { that most closely } \\
\text { resembles the result of Kt } \\
\text { from the graph }\end{array}$ \\
\hline $\begin{array}{l}\text { Kt calculation with } \\
\text { ANSYS }\end{array}$ & $\begin{array}{l}\text { Not done due to the lack } \\
\text { of results }\end{array}$ & $\begin{array}{l}\text { Have the results but } \\
\text { calculations not done }\end{array}$ & $\begin{array}{l}\text { Does not apply diameter } \\
\text { correction. } \\
\text { Errors in units } \\
\end{array}$ & $\begin{array}{l}\text { Make the correct } \\
\text { calculation but the stress } \\
\text { used is not optimal }\end{array}$ & Make the right calculation \\
\hline $\begin{array}{l}\text { Obtención Kt en la } \\
\text { gráfica }\end{array}$ & Not done & $\begin{array}{l}\text { Enter the input data } \\
\text { wrong }\end{array}$ & $\begin{array}{l}\text { Enter the data correctly, } \\
\text { but the errors reading the } \\
\text { outputs }\end{array}$ & Small mistakes & $\begin{array}{l}\text { Read correctly the value of } \\
k t \text { in the graph }\end{array}$ \\
\hline $\begin{array}{l}\text { Justificación de } \\
\text { resultados }\end{array}$ & Does not write anything & $\begin{array}{l}\text { ANSYS stress errors or } \\
\text { errors reading the graph }\end{array}$ & $\begin{array}{l}\text { Justifica el error de no } \\
\text { corregir la tensión nominal } \\
\text { con errores de } \\
\text { discretización } \\
\text { Error de unidades }\end{array}$ & $\begin{array}{l}\text { Correct calculations, } \\
\text { provide a reasonable } \\
\text { justification of the found } \\
\text { differences }\end{array}$ & $\begin{array}{l}\text { Show calculations with } \\
\text { various stresses. } \\
\text { Propose to make a better } \\
\text { refinement }\end{array}$ \\
\hline
\end{tabular}

Figure 5. Rubric to evaluate the degree of mastery of the competence.

\section{RESULTS}

The new proposal has been implemented in the three subjects detailed in the Table 1 . 
Table 1. Details of the subjects.

\begin{tabular}{|c|c|c|c|c|}
\hline Subject and year & $\begin{array}{c}\text { Total number of } \\
\text { students in the } \\
\text { subject }\end{array}$ & $\begin{array}{c}\text { Number of } \\
\text { students in the } \\
\text { practical sessions }\end{array}$ & $\begin{array}{c}\text { Number of lab } \\
\text { sessions (unguided } \\
\text { not included) }\end{array}$ & $\begin{array}{c}\text { Session } \\
\text { duration (h) }\end{array}$ \\
\hline $\begin{array}{l}\text { Technology of Machines } \\
3^{\text {rd }} \text { Year Degree }\end{array}$ & 244 & 18 & 2 & 3 \\
\hline $\begin{array}{l}\text { Technology of Machines for levelling } \\
1^{\text {st }} \text { Year Master's Degree }\end{array}$ & 31 & 14 & 3 & 3 \\
\hline $\begin{array}{l}\text { Materials Behaviour in Service } \\
1^{\text {st }} \text { Year Master's Degree }\end{array}$ & 19 & 19 & 2 & 3 \\
\hline
\end{tabular}

Table 1 shows the number of students which attended the lab sessions. Due to the pandemic, the lab sessions have been online. Therefore, students had to install the software or connect to the virtual laboratory provided by the university as a first task. In both cases students encountered unforeseen technical impediments. For that reason, the delivery was extended beyond the sessions and exceptionally it was allowed to deliver the work after the deadline. The Figure 6 graphs show the evolution of the delivery time over the year in the three subjects.

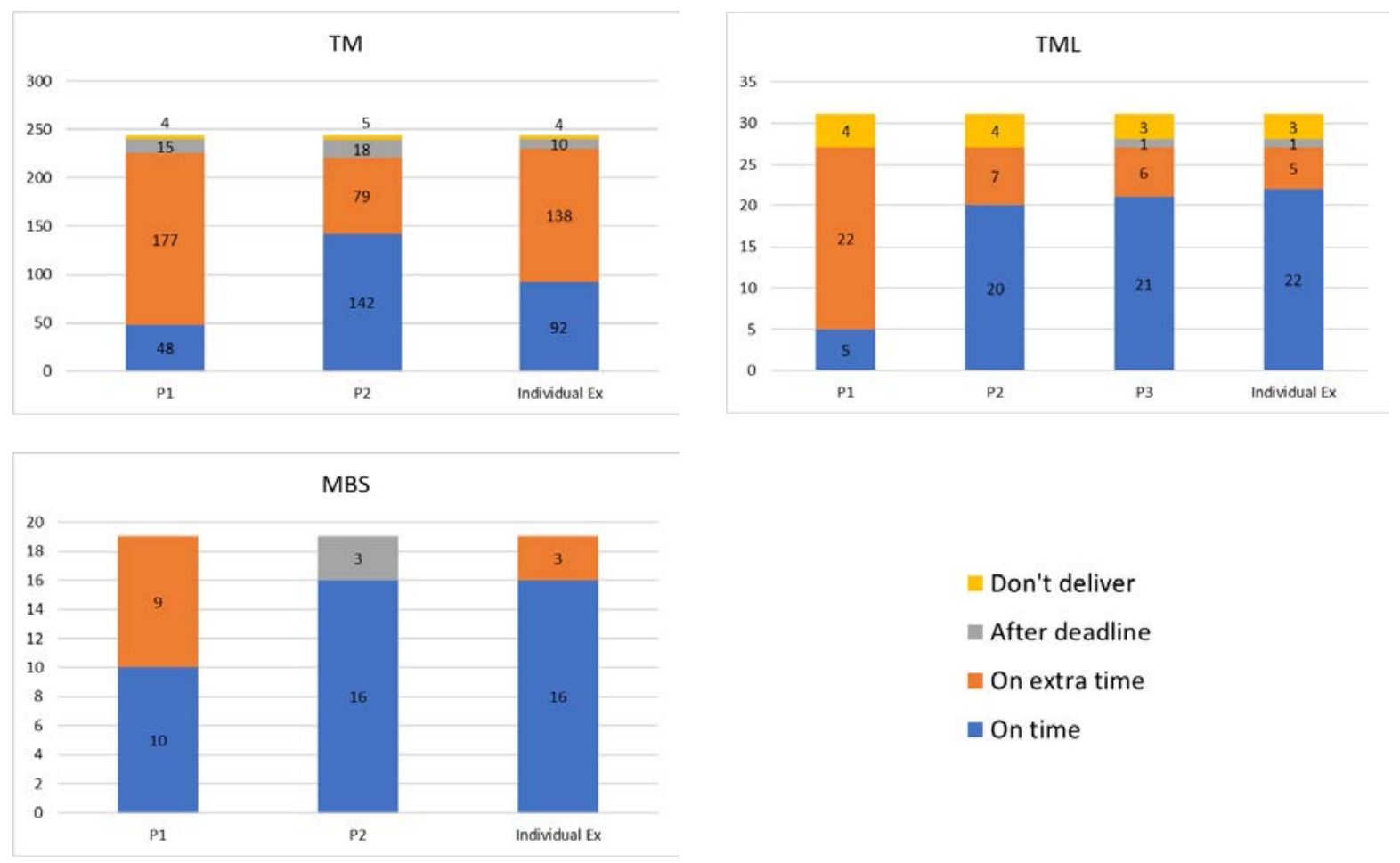

Figure 6. Deliveries of the exercise of each lab session per subject.

In general, the number of works delivered on time increases with time because students accumulate knowledge and experience with the management of the software. In all cases, the individual exercise has a greater influence on the grade, so it can justify that some students forced the delay in order to check or verify their results.

Additionally, in the subject "Behaviour of Materials in Service", a remarkable advance has been observed. Students must make a work in which they analyse the mechanical failure of a real component. The recommendation of the work is to do calculations following the theoretical models explained in the subject and/or to model the piece and its boundary conditions with the FE software. In previous years, students only did theoretical calculations, however, this year $36 \%$ of students used ANYS ${ }^{\circ}$ to obtain the numerical results of the mechanical problem. Moreover, some of them used the numerical predictions in order to validate or correct their theoretical results thus fulfilling one the objectives of the "Specific Instrumental" transversal competence, which is to achieve enough 
autonomy in managing the software in order to properly manage this kind of tools used in professional scenarios.

Furthermore, the new evaluation system implemented in the unguided exercise, discriminates the mastery with greater rigor. The Figure 7 graphs show the distribution of the marks obtained, where the average of the marks obtained in the guided lab sessions and in the individual unguided session, as well as the average of the marks of the lab sessions before the implementation of the proposed methodology (when available) are shown. In all the cases, the mean value of the marks in the individual unguided exercises is lower than both the guided exercise and the previous years, as expected. The subject TML exhibit a similar variance between the marks of the guided and unguided exercises while the subjects TM and BMS show greater differences in the mastery of the software among students.

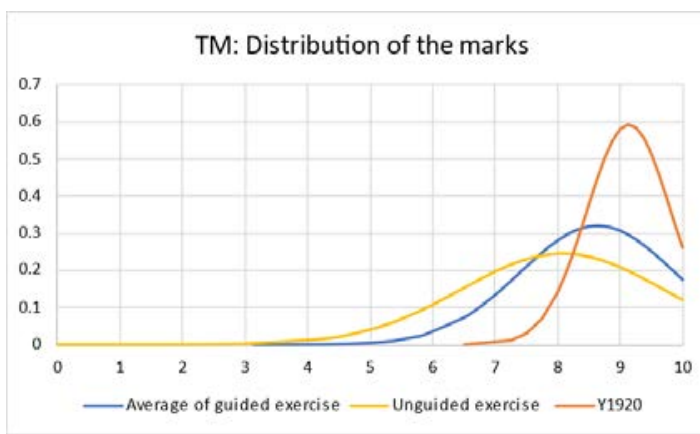

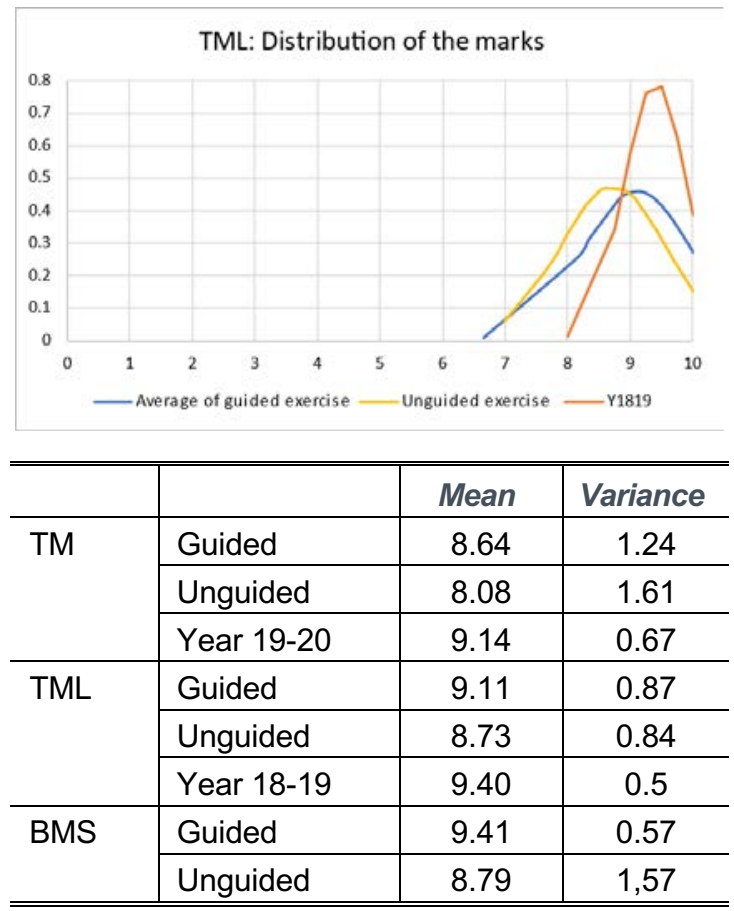

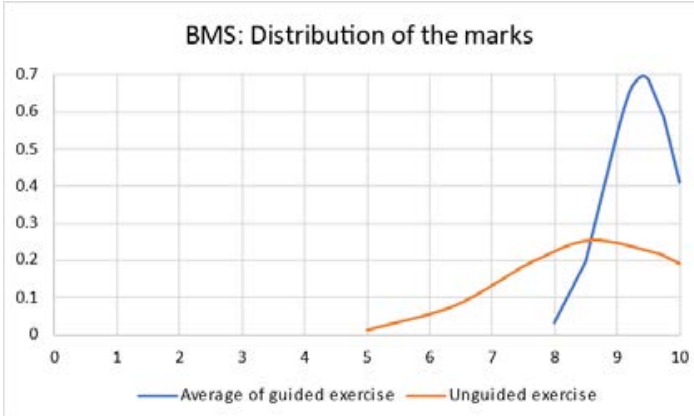

Figure 7. Distribution of the marks per subject.

\section{CONCLUSIONS}

This paper presents a methodology to work on the acquisition and evaluation of the "Specific Instrumental" transversal competence. The tool chosen is ANSYS 8 , which allows do calculations based on the FEM, and is widely used in the mechanical engineering field.

The proposed methodology has been developed and implemented in several subjects of the mechanical engineering area over the last two years. In the first year, the experience was carried out in small groups. After the first year, the methodology was improved and implemented in bigger groups.

Students learn how to manage the software during the lab sessions following a very detailed statement. In the last lab session, students must model a completely new exercise without any kind of help. The mastery of the competence is evaluated depending on the adequacy and the justifications of the steps followed in the unguided exercise. While most of students can correctly complete the guided tasks, the marks obtained in the unguided exercise show worse results and uneven level of success among students.

Regarding the COVID scenario, all lab sessions, including the unguided individual exercise, have been online. The statements have been improved by adding extra explanations and including short videos. The delivery of the exercises has been done using the online platform provided by the Universitat Politècncia de València. The lecturing material, the procedure for the deliveries and the methodology have been proved to be valid also for a post-COVID era. 


\section{ACKNOWLEDGEMENTS}

Authors gratefully acknowledge the financial support of the Vicerrectorado de Estudios, Calidad $y$ Acreditación, the Vicerrectorado de Recursos Digitales y Documentación of the Universitat Politècnica de València (Project PIME B/19-20/165 and Project PIME C/20-21/201) and the Instituto de Ciencias de la Educación of the Universitat Politècnica de València (EICE INTEGRAL).

\section{REFERENCES}

[1] P. Beneitone et al, Tuning brochure, Tuning Project: Reflexiones y perspectivas de la Educación Superior en América Latina. Informe Final-Proyecto Tuning-América Latina. Bilbao: Universidad de Deusto, 2007. Retrieved from http://tuning.unideusto.org/tuningal, 2007.

[2] Tuning project. Tunning General Brochure, Accessed 14 August, 2020. Retrieved form http://www.unideusto.org/tuningeu/documents.html

[3] Universtitat Politècnica de València, Proyecto competencias transversales UPV, Accessed 11 May, 2021. Retrieved from https://www.upv.es/entidades/ICE/info/Proyecto_Institucional_CT.pdf

[4] Universtitat Politècnica de València, Convocatoria Aprendizaje + Docencia 2019, Accessed 11 May, 2021. Retrieved from https://www.upv.es/contenidos/ICEP/info/760700normalc.html

[5] ANSYS, Accessed 11 May, 2021. Retrieved from https://www.ansys.com/

[6] A.M. Pedrosa, E.M. Sanchez-Orgaz, E. Lozano-Mínguez and S. Martinez-Sanchís, "Implementation of activities for the evaluation of the specific instrumental transversal competence in subjects in the area of mechanical engineering" in 13th International Conference of Education, Research and Innovation, 2020, ICERI 2020. pp. 597-602, 2020.

[7] R.G. Budynas and J.K. Nisbett, Shigley's mechanical engineering design. New York: McGraw-Hill, 2015. 